\title{
In house reverse membrane hybridisation assay versus GenoType MTBDRplus and their performance to detect mutations in the genes rpoB, katG and inhA
}

\author{
Sergio Luiz Montego Ferreira Junior ${ }^{1,2}$, Elis Regina Dalla Costa ${ }^{1 /+}$, Paula Gonçalves dos Santos ${ }^{3}$, \\ Harrison Magdinier Gomes ${ }^{4}$, Marcia Susana Nunes Silva ${ }^{1,5}$, Leonardo Souza Esteves ${ }^{1}$, \\ Martha Maria Oliveira ${ }^{3}$, Raquel de Abreu Maschmann ${ }^{1,2}$, Afrânio Lineu Kritski ${ }^{3}$, \\ Philip Noel Suffys ${ }^{4}$, Maria Lucia Rosa Rossetti ${ }^{1,5}$
}

\begin{abstract}
${ }^{1}$ Centro de Desenvolvimento Científico e Tecnológico, Fundação Estadual de Produção e Pesquisa em Saúde, Porto Alegre, RS, Brasil ${ }^{2}$ Programa de Pós-Graduação em Biologia Celular e Molecular, Centro de Biotecnologia, Universidade Federal do Rio Grande do Sul, Porto Alegre, RS, Brasil ${ }^{3}$ Programa Acadêmico de Tuberculose, Instituto de Doenças do Tórax, Hospital Universitário Clementino Fraga Filho, Faculdade de Medicina, Universidade Federal do Rio de Janeiro, Rio de Janeiro, RJ, Brasil ${ }^{4}$ Laboratório de Biologia Molecular Aplicada a Micobactérias, Instituto Oswaldo Cruz-Fiocruz, Rio de Janeiro, RJ, Brasil ${ }^{5}$ Universidade Luterana do Brasil, Canoas, RS, Brasil
\end{abstract}

Drug-resistant tuberculosis (TB) threatens global TB control and is a major public health concern in several countries. We therefore developed a multiplex assay (LINE-TB/MDR) that is able to identify the most frequent mutations related to rifampicin (RMP) and isoniazid (INH) resistance. The assay is based on multiplex polymerase chain reaction, membrane hybridisation and colorimetric detection targeting of $\mathrm{rpo} B$ and $\mathrm{kat} G$ genes, as well as the inhA promoter, which are all known to carry specific mutations associated with multidrug-resistant TB (MDR-TB). The assay was validated on a reference panel of $108 \mathrm{M}$. tuberculosis isolates that were characterised by the proportion method and by DNA sequencing of the targets. When comparing the performance of LINE-TB/MDR with DNA sequencing, the sensitivity, specificity and agreement were $100 \%, 100 \%$ and $100 \%$, respectively, for RMP and $77.6 \%$, $90.6 \%$ and $88.9 \%$, respectively, for INH. Using drug sensibility testing as a reference standard, the performance of LINE-TB/MDR regarding sensitivity, specificity and agreement was $100 \%, 100 \%$ and $100 \%$ (95\%), respectively, for RMP and $77 \%, 100 \%$ and $88.7 \%$ (82.2-95.1), respectively, for INH. LINE-TB/MDR was compared with GenoType MTBDRplus for 65 isolates, resulting in an agreement of 93.6\% (86.7-97.5) for RIF and 87.4\% (84.3-96.2) for INH. LINE-TB/MDR warrants further clinical validation and may be an affordable alternative for MDR-TB diagnosis.

Key words: Mycobacterium tuberculosis - resistance - hybridisation

Tuberculosis (TB) is one of the most important public health problems, with eight million new cases and 1.4 million deaths reported each year (WHO 2011). In 2008, the World Health Organization (WHO) reported a considerable increase in multidrug-resistant TB (MDRTB) cases (Loddenkemper \& Hauer 2010); this situation was even more dramatic in regions with a high rate of human immunodeficiency virus (HIV) infection (Padmapriyadarsini et al. 2011). The emergence and spread of these isolates, particularly the extensively drug-resistant isolates TB, is a serious problem for TB control programs. The problem is particularly serious in developing countries, where only $8.5 \%$ of MDR-TB cases are diagnosed and an even lower proportion of cases have access to appropriate treatment (WHO 2010). Several other factors are responsible for this global TB scenario, of which most are related to economic and social issues,

doi: 10.1590/0074-0276130469

Financial support: ICOHRTA AIDS/TB (\# 5 U2R TW006883-02), INCT (573548/2008-0)

ALK and MLRR are recipients of a career award from CNPq, FAPERJ and FAPERGS.

+ Corresponding author: dallacostaer@gmail.com

Received 23 September 2013

Accepted 15 January 2014 such as poverty, drug addiction and a lack of access to health programs (Watterson et al. 1998, Rylance et al. 2010). While approximately $14 \%$ of new TB cases worldwide are MDR, this number can reach up to $50 \%$ among previously treated patients and in certain regions (WHO 2012). In developing nations, drug susceptibility testing (DST) is still carried out using phenotypic methods. The most common phenotypic method, a culture on Löwenstein-Jensen (LJ) solid medium, is an inexpensive and relatively simple procedure; however, it requires trained workers and the results are not available until several weeks after the primary culture (MS 2010). Therefore, there is a need for accurate and low-cost diagnostic assays for both drug-susceptible and drug-resistant TB. In the case of rifampicin (RMP), approximately $95 \%$ of the Mycobacterium tuberculosis isolates (Campbell et al. 2011, Crudu et al. 2012) are resistant (RMP-R) due to single nucleotide polymorphisms (SNPs), which are small deletions or insertions primarily within an $81 \mathrm{bp}$ region of the rpoB gene and are mainly found in codons 531, 526 and 516 (Zaczek et al. 2009, Kozhamkulov et al. 2011).

Isoniazid resistance (INH-R) is more complex and is associated with mutations in one or more genes, such as the genes encoding catalase-peroxidase $[k a t G$ gene (codon 315)] and the enoyl-acyl-carrier protein reductase enzyme, which is involved in mycolic acid biosynthesis [inhA (-15 nucleotide)] (Vilch \& Jacobs 2007). Com- 
mercial methods based on genotyping are available for the simultaneous identification of Mycobacterium at the species level and the detection of resistance to the primary first-line drugs, such as GeneXpert (Dorman et al. 2012) and GenoType MTBDRplus (Hain Lifesciences) (Ling et al. 2008), for detecting RMP-R and INH-R, respectively. However, the phenotypic or genotypic characterisation of every $M$. tuberculosis isolate or sputum sample containing acid-fast bacilli is currently time consuming, costly and feasible only in low TB burden countries; it is not feasible in the developing countries where TB and MDR-TB are of major concern (Rylance et al. 2010). Therefore, in 2010, the WHO recommended that new rapid diagnostic methods be developed to help prevent TB transmission, especially the transmission of resistant bacilli (WHO 2011).

The goal of the present study was to develop a molecular assay based on the reverse hybridisation of membranes with rapid detection of the mutations that are most frequently related to RMP-R and INH-R M. tuberculosis. Direct polymerase chain reaction (PCR) sequencing and GenoType MTBDRplus were used as the reference methods and were performed on the same set of samples.

\section{MATERIALS AND METHODS}

Cultures, susceptibility testing and DNA extraction - One hundred and eight cultures had previously been tested for drug susceptibility using the Ogawa-Kudoh standard proportion method (Canetti et al. 1963) at the Central Laboratory of Rio Grande do Sul (IPB/LACENRS), the regional reference laboratory for Mycobacterium-related disease in the city of Porto Alegre, South
Region of Brazil. This study was approved by the Ethical Committee of the School of Public Health and the State Foundation of Health Research and Production of Brazil under protocols 465/09 and 03/2010, respectively.

Nucleic acids were extracted from the M. tuberculosis culture using the cetyl trimethylammonium bromide method, as described previously (van Soolingen et al. 1994) at the Centre of Scientific and Technological Development of the State Foundation in Production and Health Research, Porto Alegre. The genes encoding $r p o \mathrm{~B}, k a t \mathrm{G}$ and the $\operatorname{inh} \mathrm{A}$ promoter, which are related to RMP and INH, respectively, had been sequenced as part of an earlier study (Verza et al. 2009, Maschmann et al. 2011). The H37Rv (ATCC27294) reference strain was used as a control for both DST and genotyping.

Amplification of part of rpoB, katG, inhA and IS6110 - The multiplex PCR was performed using the primers described in Supplementary data. The reverse primers were biotin labelled and the PCR-multiplex was standardised in a final volume of $50 \mu \mathrm{L}$ containing $200 \mu \mathrm{M}$ of each dNTP, $10 \mathrm{mM}$ Tris- $\mathrm{HCl}$ (pH 8.3), $50 \mathrm{mM} \mathrm{KCl,} 2$ $\mathrm{mM} \mathrm{MgCl}, 10$ pmoles of primers Rif1 and Rif2 each, 25 pmoles of primers kat $\mathrm{G} 1$ and $k a t \mathrm{G} 2, \operatorname{inh} \mathrm{A} 1$ and $i n h \mathrm{~A} 2$ and IS1 and IS2 each, $2.5 \mathrm{U}$ of Taq DNA polymerase (Invitrogen/USA) and $1 \mu \mathrm{L}(100 \mathrm{ng} / \mu \mathrm{L})$ of purified bacterial DNA. The PCR reactions were carried out as follows: $3 \mathrm{~min}$ at $95^{\circ} \mathrm{C}, 30$ cycles of $1 \mathrm{~min}$ at $95^{\circ} \mathrm{C}, 1 \mathrm{~min}$ at $60^{\circ} \mathrm{C}, 1.5 \mathrm{~min}$ at $72^{\circ} \mathrm{C}$ and $4 \mathrm{~min}$ at $72^{\circ} \mathrm{C}$. Each amplification experiment included a positive (M. tuberculosis H37Rv DNA, $100 \mathrm{ng}$ ) and a negative control (water). For standardisation of the amplification reactions, the PCR

TABLE I

Correlation between LINE-TB/MDR and sequencing

\begin{tabular}{|c|c|c|c|c|}
\hline \multicolumn{2}{|r|}{ LINE-TB/MDR pattern } & \multirow{2}{*}{$\begin{array}{l}\text { LINE-TB/MDR } \\
\text { result-location } \\
\text { of mutation }\end{array}$} & \multicolumn{2}{|c|}{ Sequencing data } \\
\hline $\begin{array}{l}\text { Positive } \\
\text { probes }\end{array}$ & Gene (probe) & & $\begin{array}{l}\text { Nucleotide/amino } \\
\text { acid changes }\end{array}$ & $\begin{array}{l}\text { Strains } \\
\mathrm{n}(\%)\end{array}$ \\
\hline $1,2,3,4^{*}$ & $\operatorname{rpoB}($ Rif4M) & S531L & TCG-TTG/Ser-Leu & $37(69.8)$ \\
\hline $1,2,3,4^{*}$ & rpoB (Rif5M) & S531W & TCG-TGG/Ser-Trp & $1(1.88)$ \\
\hline $1,2,4,5^{*}$ & rpoB (Rif3M) & H526D & CAC-GAC/His-Asp & $4(7.5)$ \\
\hline $1,3,4,5^{*}$ & rpoB (Rif2M) & H526Y & CAC-TAC/His-Tyr & $4(7.5)$ \\
\hline $1,2,3,5^{*}$ & Lack hybridisation & H526L & CAC-GTC/His-Leu & $1(1.88)$ \\
\hline $1,2,3,5^{*}$ & Lack hybridisation at (Rif2/3M) & H526R & CAC-CGC/His-Arg & $1(1.88)$ \\
\hline $1,2,3,5^{*}$ & Lack hybridisation at (Rif2/3M) & H526P & CAC-CCC/His-Pro & $1(1.88)$ \\
\hline $1,2,3,5^{*}$ & Lack hybridisation at (Rif2/3M) & H526L & CAC-CTC/His-Leu & $1(1.88)$ \\
\hline $1,3,4,5^{*}$ & Lack hybridisation at (Rif2/3M) & D516Y & GAC-TAC/Asp-Tyr & $2(3.77)$ \\
\hline $1,3,4,5^{*}$ & rpoB (Rif1M) & D516V & GAC-GTC/Asp-Val & $1(1.88)$ \\
\hline $11^{*}$ & $\operatorname{inh} \mathrm{A}(\operatorname{inh} A M)$ & -15 & $\mathrm{C}-\mathrm{T}$ & $13(24.6)$ \\
\hline $12 *$ & inhA (inhAwt) & No mutation & WT & $40(75.4)$ \\
\hline $14 *$ & Kat $\mathrm{G}($ katGM) & S315T & AGC-ACC/Ser-Thr & $41(77.3)$ \\
\hline $13 *$ & katg (katGwt) & No mutation & WT & $12(22.7)$ \\
\hline $1,2,3,4,5,12,14^{*}$ & WT & No mutation & WT & $55(100)$ \\
\hline
\end{tabular}

WT: wild type. 
products were analysed using polyacrylamide gel electrophoresis, followed by detection in ultraviolet light after staining with ethidium bromide and comparison of the amplicons to a molecular weight marker.

Reverse-line blot hybridisation and colorimetric detection - Reverse hybridisation and colorimetric detection were performed based on the previously described protocol (Maschmann et al. 2011, Michelon et al. 2011), with some modifications. The membranes were washed in $2 \mathrm{x} \mathrm{SSC} / 0.1 \%$ sodium dodecyl sulfate (SDS) for $5 \mathrm{~min}$ at $50^{\circ} \mathrm{C}$ and were incubated in $2 x$ SSC with $5 \%$ bovine serum albumin (BSA) at $50^{\circ} \mathrm{C}$ for $15 \mathrm{~min}$. Twenty-five microlitres of each PCR reaction was added to $150 \mu \mathrm{L}$ of $2 \mathrm{x} \mathrm{SSC} / 0.1 \%$ SDS and the mixture was denatured at $100^{\circ} \mathrm{C}$ for $10 \mathrm{~min}$ and then transferred to an ice bath. The denatured PCR product was then added to a polyethylene tube containing a membrane in $1.4 \mathrm{~mL}$ of the hybridisation solution ( $2 \times \mathrm{SSC} / 0.1 \% \mathrm{SDS})$. Hybridisation was achieved by incubation at $62^{\circ} \mathrm{C}$ for $30 \mathrm{~min}$. After hybridisation, the membranes were washed in $2 \mathrm{x}$ SSC $/ 0.5 \%$ SDS at $57^{\circ} \mathrm{C}$ for $10 \mathrm{~min}$ each. The membranes were then treated with Tris-buffered saline (TBS) $(100 \mathrm{mM}$ Tris- $\mathrm{HCl}$, $150 \mathrm{mM} \mathrm{NaCl}, \mathrm{pH} 7.5$ ) containing $6 \%$ BSA for $30 \mathrm{~min}$ at $50^{\circ} \mathrm{C}$. The membranes were incubated in TBS containing $0.33 \mu \mathrm{g} / \mathrm{mL}$ streptavidin-alkaline phosphatase (AP) conjugate for $15 \mathrm{~min}$ at room temperature (RT). The unbound conjugate was removed by washing in TBS for 10 min followed by the addition of AP buffer ( $100 \mathrm{mM}$ Tris$\mathrm{HCl}, 150 \mathrm{mM} \mathrm{NaCl}$ and $\left.5 \mathrm{mM} \mathrm{MgCl} \cdot 6 \mathrm{H}_{2} \mathrm{O}, \mathrm{pH} 9.5\right)$ for $10 \mathrm{~min}$ at RT. The hybridisation was visualised by adding $40 \mu \mathrm{g} / \mathrm{mL}$ 5-bromo-4-chloro-3-indoyl phosphatase and $82.5 \mu \mathrm{g} / \mathrm{mL}$ nitro blue tetrazolium (Sigma) in the AP buffer and incubation for $10 \mathrm{~min}$ at RT. A purple precipitate was observed when there was a perfect match between the probe and the biotinylated PCR product. The colorimetric reaction was blocked with distilled water and the membranes were dried at RT.

Sensitivity and specificity of the assay - The analytical sensitivity of the test was determined by performing the assay with a serial 10 -fold dilution of $M$. tuberculosis H37Rv DNA (100 ng to $1 \mathrm{pg}$ ). To determine the specificity of LINE-TB/MDR, $100 \mathrm{ng}$ of genomic DNA from each of the following bacteria were submitted to the entire procedure: Neisseria meningitidis, Streptococcus pneumoniae, Salmonella enterica, Haemophilus influenzae, Escherichia coli (obtained from IPB/LACENRS), Mycobacterium marinum, Mycobacterium intracellulare, Mycobacterium scrofulaceum, Mycobacterium gordonae, Mycobacterium avium, Mycobacterium smegmatis, Mycobacterium kansasii, Mycobacterium xenopi, Mycobacterium fortuitum-peregrinum and Mycobacterium phlei (obtained from Oswaldo Cruz Foundation, Brazil) (Verza et al. 2009, Maschmann et al. 2011).

Probe design and binding to membrane - The oligonucleotide probes were designed using the Software Primer express v.2.0 (Applied Biosystems). Our final assay setup was composed of (i) five probes for the wild type (WT) rpoB allele and five probes for each of the different $r p o \mathrm{~B}$ mutant alleles, (ii) one probe each for the WT and mutant kat $\mathrm{G}$ and (iii) one probe each for the
WT and mutant inhA promoter alleles. Additionally, we designed a probe specific for hybridisation with the insertion sequence IS6110 (Supplementary data).

For the immobilisation of the DNA probes, a negatively-charged nylon membrane (Biodyne C, Pall Corporation) was activated in a solution of $16 \%(\mathrm{w} / \mathrm{v})$ (1-(3-dimethylaminopropyl)-3-ethylcarbodiimide hydrochloride) (Acros Organics) for $20 \mathrm{~min}$ at RT and was washed in distilled water for $2 \mathrm{~min}$ at RT. Then, $10 \mu \mathrm{L}$ of each of the oligonucleotide probes, containing a 5'terminal amino group, were diluted to the appropriate concentration (Supplementary data) in $0.5 \mathrm{M} \mathrm{NaHCO}_{3}$ ( $\mathrm{pH} 8.4$ ) and plotted into 15 circles $(5 \mathrm{~mm})$ previously designed on the membrane, followed by incubation for $1 \mathrm{~min}$ at RT. The membranes were then incubated in 0.1 $\mathrm{M} \mathrm{NaOH}$ for $10 \mathrm{~min}$, washed in distilled water for $2 \mathrm{~min}$ at RT, washed in $2 \mathrm{x} \mathrm{SSC} / 0.1 \% \mathrm{SDS}$ for $10 \mathrm{~min}$ at $50^{\circ} \mathrm{C}$ and finally incubated in $20 \mathrm{mM}$ EDTA (pH 8.0) for 15 $\min$ at RT. The membranes were finally transferred into a polyethylene tube and stored at $4^{\circ} \mathrm{C}$ for later use.

Assay interpretation - The panel $\mathrm{F}$ in Figure demonstrates the positions of the probes for $r p o \mathrm{~B}, k a t \mathrm{G}, \operatorname{inh} \mathrm{A}$ and IS6110. A hybridisation result was considered positive when a purple colour was observed in the circle where a particular probe had been plotted. The probes in rpoB were located within the $81 \mathrm{bp}$ resistance-determining region (RDR) and hybridisation with all five WT probes was considered to indicate an RMP-susceptible strain. When one of these signals was lacking, independent of any hybridisation to probes $6-10$, the strain was considered to be an rpoB-mutated strain. A strain was considered mutated for the inhA gene when there was a lack of hybridisation to probe 12 and/or hybridisation to probe 11 occurred; the WT kat G gene was represented by hybridisation to probe 13 and a positive signal for probe 14 was observed when the gene was mutated. The hybridisation to probe 15 (IS6110) was an additional confirmation of the M. tuberculosis complex (MTBC).

GenoType $^{\circledR}$ MTBDRplus assay - The GenoType MTBDRplus assay was performed according to the manufacturer's instructions (Crudu et al. 2012). Of the 108 previously selected samples, 65 were tested using the GenoType MTBDRplus assay. In order to guarantee the highest fidelity possible between the LINE-TB/MDR assay and the GenoType MTBDRplus assay, the same DNA aliquot was used in both experiments.

\section{RESULTS}

A positive hybridisation signal was observed with the probe specific for IS6110 for all 108 isolates; no non-mycobacterial DNAs or Mycobacterium species other than those of the MTBC presented a signal at this membrane region. The test was therefore $100 \%$ sensitive and specific for strains belonging to the MTBC (A in Figure). Among the 108 cultures, 55 were considered sensitive to both of the drugs and presented the WT alleles for $r p o \mathrm{~B}$, $k a t \mathrm{G}$ and $i n h \mathrm{~A}$ in the DST. Sequence analysis demonstrated the presence of at least one mutation in the rpoB gene in 53 of the MDR-TB samples and among these, 31 presented an additional mutation in $k a t \mathrm{G}$. There were 
also three samples that presented mutations in the $i n h \mathrm{~A}$ promoter region and 10 presented mutations in both $\mathrm{kat} \mathrm{G}$ and inhA. Nine isolates (17\%) had no mutation in either of the INH-R-associated genes (Table I).

The LINE-TB/MDR method achieved 100\% sensitivity (55/55) among the WT samples and, as such, identified the INH-S and RMP-S isolates; this was demonstrated by hybridisation to the five WT rpoB probes (probes 1-5) and the WT inh A and kat G probes (probes 12 and 13) (A in Figure).

Among the 53 MDR strains, 38 had a mutation in codon 531. The LINE-TB/MDR assay was able to correctly identify all of the mutations occurring at codon 531 when the SNP involved resulted in an amino acid (a) change of Ser $\rightarrow$ Leu; these strains exhibited hybridisation signals with probes 1 through 4 and 9, but had a lack of hybridisation to probe five (B in Figure). Among the 12 additional isolates with $r p o B$ mutations, the LINE-TB/MDR method correctly identified eight codon 526 mutants, of which four presented a His $\rightarrow$ Asp aa change and four presented a His $\rightarrow$ Tyr aa change. Codon 516 in the LINE-TB/MDR assay correctly identified a single strain that had the Asp $\rightarrow$ Val aa change. Four mutants at codon 526 and two mutants at codon 516 did not have a complementary mutant probe in our assay, but they lacked hybridisation signals with the WT 526 probe 4 , as expected, and probe 2, which represented the WT codon 516 (E in Figure). The comparison of the results obtained for all of the isolates using the LINE-TB/MDR assay $(\mathrm{n}=108)$ and the $r p o B$ RDR sequencing as a reference is summarised in Table II. This assay reported a Kappa value ( $\mathrm{k}$ ) [95\% confidence interval (CI)] and agreement of 1 (99.5-100.0).

We also evaluated the performance of the LINE-TB/ MDR method in 53 INH-resistant isolates. According to the sequence data, 44 of these isolates carried mutations in $k a t G$ and/or inhA and 41 (77.3\%) were $k a t G 315$ (AGCACC) (Ser $\rightarrow$ Thr). Among these samples, the LINE-TB/ MDR method was able to correctly identify $36(88 \%)$, with a positive signal at probe $14(\mathrm{~kat} G \mathrm{M})$ and a lack of hybridisation at probe 13 (kat GWT) (C in Figure). Three isolates with a mutation in codon 315 gave a positive signal for probe 13 ( $k a t \mathrm{GWT})$, while two of the isolates did not hybridise to any of the $k a t \mathrm{G}$ probes ( $\mathrm{E}$ in Figure). Among the 12 isolates, 11 (91.6\%) hybridised to probe 13 ( $k a t G \mathrm{WT}$ ), as expected, but one isolate again failed to hybridise to any of the kat $\mathrm{G}$ probes. In addition, 40 of the 53 MDR strains (75.4\%) presented a WTinhA genotype; among these, 37 (92.5\%) showed hybridisation to probe 12 (inhAWT) and a lack of hybridisation to probe 11 (inhAM) (D in Figure). Three isolates presented discordant results when compared to the sequencing data; one sample hybridised to probe 11, corresponding to a mutated region of the gene (inh $A \mathrm{M})$, while two isolates did not hybridise to any of the inhA probes $(i n h A M)$. The other strains ( $\mathrm{n}=13$; $25 \%$ ) contained the mutation $\mathrm{C}-15 \mathrm{~T}$ in the promoter region of inhA and 10 (77\%) strains correctly demonstrated hybridisation to probe 11 (inh $A \mathrm{M})$, while three failed to hybridise to either probe 11 or 12 . In conclusion, the overall results of the LINE-TB/MDR assay $(n=108)$ and the combined sequences of $k a t \mathrm{G}$ and $\operatorname{inh} \mathrm{A}$ demonstrated a $\mathrm{k}$ $(95 \% \mathrm{CI})$ of $0.889(82.5-95.2)$ for $k a t \mathrm{G}$ and $i n h \mathrm{~A}$ and an negative predictive value and positive predictive value of $94.8 \%$ and $100 \%$, respectively (Table II).

Sixty-five of the 108 isolates were also analysed using the GenoType MTBDRplus assay and 25 susceptible strains with WT, INH and RMP sequences were correctly identified. Among the 40 RIF-resistant strains that also had RMP-R genotypes, 37 (92.5\%) were recognised correctly by MTBDRplus, while three were identified as WT strains. The concordance rates between the LINE-TB/ MDR and MTBDRplus assays for drug resistance (DR)
A

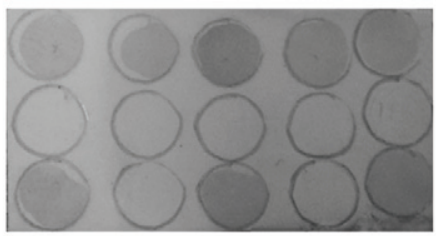

D

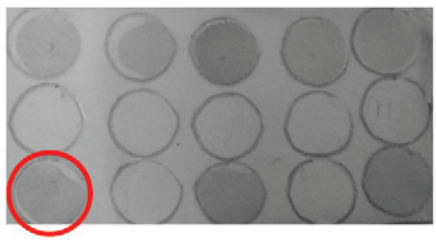

B

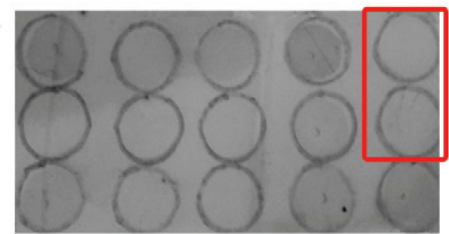

E

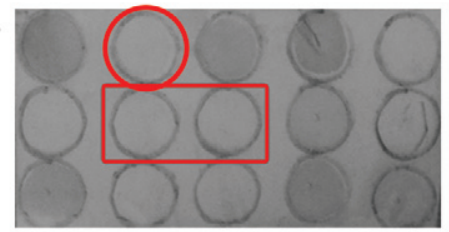

C
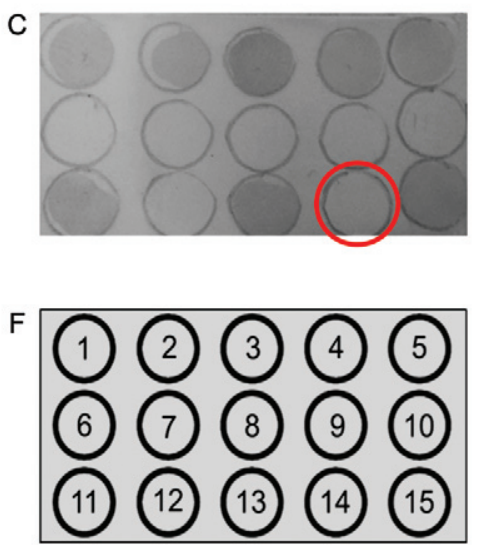

A: example of the wild type (WT) result to the three genes rpoB, kat $\mathrm{G}$ and inhA; B: example of a strain mutated in the 531 region of the rpoB gene with no hybridisation with the Rif5wt probe and hybridisation with the Rif4M; C: hybridisation with the 14 kat GM probe; D: hybridisation with the probe number 11; E: hybridisation was not observed with the rif4 probe, what suggested that there are mutation in the rpoB gene codon 526, although the method have not allowed to identified the mutation; F: schematic presentation of LINE-TB/MDR. Probes position: rpoB WT probes, circles 1-5 (Rif 1, Rif 2, Rif 3, Rif 4, Rif 5); rpoB mutated probes, 6-10 (Rif1M, Rif2M, Rif3M, Rif4M, Rif5M); 11, inhAM; 12, inhAwt; 13, katGwt; 14, katGM; 15 , IS6110. 
detection in these samples were $93.6 \%(63 / 65)$ for the INH sequences and $87.4 \%(62 / 65)$ for the RMP sequences (Table III). The MTBDRplus did not identify three RMP-R strains that were correctly identified by LINE-TB/MDR and sequencing and three sequencing-confirmed INH-R isolates were not identified by LINE-TB/MDR.

\section{DISCUSSION}

MDR-TB is defined by simultaneous resistance to INH and RMP, the main drugs used for TB treatment (Laurenzo \& Mousa 2011). Because M. tuberculosis is a clonal organism, most of the acquisition of DR in $M$. tuberculosis is due to point mutations in the chromosome (Sreevatsan et al. 1997, Ramaswamy \& Musser 1998) that accumulate and are preserved in the different lineages (Brosch et al. 2002, Smith et al. 2003). These traits of Mycobacterium render it suitable for the development of assays for the detection and eventual characterisation of the presence of well-described INH-R and RMP-R SNPs (Cardoso et al. 2004, Arnold et al. 2005, Campbell et al. 2011). In Brazil, as recommended by the Ministry of Health, TB diagnosis and DST can be performed using solid media (LJ or Ogawa-Kudoh) and liquid media (Middlebrook 7H10), but these methods have several limitations, mainly related to the delay of diagnosis, which can be as long as 12 weeks (MS 2010). For DR detection, tests based on reverse blot hybridisation probes, such as the Line Probe Assay (INNO-LiPA assay Rif TB, Innogenetics) and the GenoType MTBDRplus assay, are cur- rently widely used in many countries. These tests have sensitivities ranging from $71-100 \%$ and specificities of 96-100\% (Bwanga et al. 2009, Ajbani et al. 2012). While INNO-LiPA is restricted to the identification of RMP resistance, GenoType is able to identify both RMP and INH resistance. However, both of these methods are expensive and not widely available in developing countries (Mäkinen et al. 2006, Maschmann et al. 2013). Recently, a molecular test for the detection of M. tuberculosis and mutations conferring RMP resistance directly from sputum (GeneXpert, Cepheid Sunnyvale, CA, USA) was developed, but the performance characteristics of this procedure might be different when implemented in environments with low or high TB burdens (Dorman et al. 2012, Lawn et al. 2013). For the evaluation of our reverse hybridisation-based assay for the detection of RMP-R and INH-R, we chose a panel of strains with mutations similar to those reported in other publications. The mutations were predominantly localised in codons 531, 526 and 516 of the rpoB gene (Sekiguchi et al. 2007) in codon 315 of the kat $\mathrm{G}$ gene (Rouse et al. 1996, Arago et al. 2007) and at position -15 of the inh A regulatory region (Palomino 2009). All of the 108 isolates analysed by LINE-TB/MDR showed specific hybridisation to the IS6110 probe, which was used for M. tuberculosis identification (amongst other members of the MTBC), indicating that this method can be a reliable tool for TB diagnosis. This result is similar to that found previously by our research group when testing a method to detect

TABLE II

Comparison of the results obtained for the identification of mutation with the sequencing and with drug susceptibility testing (DST)

\begin{tabular}{|c|c|c|c|c|c|c|c|c|c|c|}
\hline & \multicolumn{2}{|c|}{$\begin{array}{l}\text { Results } \\
(\mathrm{n}=108)\end{array}$} & \multicolumn{8}{|c|}{$\begin{array}{l}\text { Compared results } \\
\qquad(\mathrm{n}=108)\end{array}$} \\
\hline & $\begin{array}{l}\text { LINE-TB/ } \\
\text { MDR }\end{array}$ & Seq & $\begin{array}{l}\text { LINE-TB/ } \\
\text { MDR } \\
\text { wt/Seq wt }\end{array}$ & $\begin{array}{l}\text { LINE-TB/ } \\
\text { MDR } \\
\text { mut/Seq wt }\end{array}$ & $\begin{array}{c}\text { LINE-TB/ } \\
\text { MDR } \\
\text { wt/Seq mut }\end{array}$ & $\begin{array}{c}\text { LINE-TB/ } \\
\text { MDR } \\
\text { mut/Seq mut }\end{array}$ & $\begin{array}{c}\text { Kappa } \\
(95 \% \text { CI })\end{array}$ & $\mathrm{p}$ & $\begin{array}{l}\mathrm{SE} \\
(\%)\end{array}$ & $\begin{array}{l}\mathrm{SP} \\
(\%)\end{array}$ \\
\hline INH wt & 58 & 64 & & & & & & & & \\
\hline INH res & 50 & 44 & 58 & 3 & 3 & 44 & $\begin{array}{c}88.9 \\
(82.5-95.2)\end{array}$ & $<0.001$ & 77.6 & 90.6 \\
\hline \multirow[t]{2}{*}{$\begin{array}{l}\text { RMP wt } \\
\text { RMP res }\end{array}$} & $\begin{array}{l}55 \\
53\end{array}$ & $\begin{array}{l}55 \\
53\end{array}$ & 55 & 0 & 0 & 53 & $\begin{array}{c}100 \\
(99.5-100.0)\end{array}$ & $<0.001$ & 100 & 100 \\
\hline & $\begin{array}{l}\text { LINE-TB/ } \\
\text { MDR }\end{array}$ & DST & $\begin{array}{l}\text { LINE-TB/ } \\
\text { MDR } \\
\text { wt/DST-S }\end{array}$ & $\begin{array}{c}\text { LINE-TB/ } \\
\text { MDR } \\
\text { mut/DST-S }\end{array}$ & $\begin{array}{l}\text { LINE-TB/ } \\
\text { MDR } \\
\text { wt/DST-R }\end{array}$ & $\begin{array}{c}\text { LINE-TB/ } \\
\text { MDR } \\
\text { mut/DST-R }\end{array}$ & $\begin{array}{c}\text { Kappa } \\
(95 \% \text { CI })\end{array}$ & $\mathrm{p}$ & $\begin{array}{l}\mathrm{SE} \\
(\%)\end{array}$ & $\begin{array}{l}\text { SP } \\
(\%)\end{array}$ \\
\hline INH wt & 55 & 55 & & & & & & $<0.001$ & 77 & 100 \\
\hline INH res & 41 & 53 & 55 & 0 & 12 & 41 & $(82.2-95.1)$ & & & \\
\hline $\begin{array}{l}\text { RMP wt } \\
\text { RMP res }\end{array}$ & $\begin{array}{l}55 \\
53\end{array}$ & $\begin{array}{l}55 \\
53\end{array}$ & 55 & 0 & 0 & 53 & $\begin{array}{c}100 \\
(99.5-100.0)\end{array}$ & $<0.001$ & 100 & 100 \\
\hline
\end{tabular}

CI: confidence interval; INH: isoniazid; RMP: rifampicin; SE: sensitivities; SP: specificities. 
TB (DETEC-TB) (Michelon et al. 2011). In addition, the 55 DNA samples that did not contain mutations in the genes associated with resistance and were drug susceptible according to the DST, were correctly identified by the LINE-TB/MDR method. Of the 53 samples with mutations in the rpoB gene, $100 \%$ (53/53) hybridised to at least one rpoB-mutated probe or showed no hybridisation to the WT probe, confirming that the isolate was not susceptible to RMP; there was complete agreement $(\mathrm{k}=1)$ between the current test and the sequencing results (Table II). These data suggest that the LINE-TB/ MDR method can be used to reliably detect resistance to this drug, as observed by Aslan et al. (2008), when using a commercial kit and samples, both mutated or not, in the rpoB gene. When SNPs for which a mutant probe was developed were present, we observed a corresponding signal for that mutant and a lack of hybridisation to the WT probe. Four isolates carried SNPs that had no mutant probe represented and, as expected, demonstrated a lack of signal in the WT probe only (E in Figure), which indicated the presence of an SNP associated with RMP-R. The sensitivity for detecting RMP resistance was $100 \%$, with sequencing used as the reference method. This is promising for the rapid detection of MDR/ TB isolates because RMP mono-resistant isolates are rarely observed (Malhotra et al. 2010). Previous studies reported that approximately $95-100 \%$ of RMP-resistant clinical isolates carry mutations in an 81 bp region of the rpoB gene (Palomino 2009). Therefore, in cases with a lack of SNPs in this region, we do not expect our assay to be useful for detecting RMP-R. Although most of the methods used to detect mutations related to INH resistance use only the kat $\mathrm{G}$ gene as a target, Maschmann et al. (2011) demonstrated that the concomitant evaluation of kat $\mathrm{G}$ and the $i n h \mathrm{~A}$ regulatory region improves sensitivity for identifying INH resistance (Aslan et al. 2008). In this study, only three INH-resistant isolates had mutations in the inhA gene, but the frequency of INH-resistant isolates containing the SNP $(\mathrm{C} \rightarrow \mathrm{G})$ at position 315 of $k a t G$ (Ser $\rightarrow \mathrm{Thr}$ ) ranged from $50-100 \%$ in the literature, including literature from Brazil (Hillemann et al. 2005, Costa et al. 2009). This aa change seems to lead to a decrease in catalase peroxidase enzyme activity, which has been described as essential for the activation of the drug (Zhang et al. 2005, Sekiguchi et al. 2007). When the LINE-TB/MDR method was compared to DST, which is a reference for MDR/TB identification, the overall agreement was $88.7 \%$ (82.2-95.1). Among the 12 DNA samples that were not correctly identified as INH-resistant, nine were found to have an inhA and $k a t G$ WT genotype by sequencing even though they were identified as MDR by DST; only three showed no hybridisation to the probes used in our assay. Some studies report that approximately $10-30 \%$ of INH-R $M$. tuberculosis strains have no mutations in DR-associated genes (Hillemann et al. 2005) and may have other resistance mechanisms, such as efflux pumps or cell envelope permeability (Mäkinen et al. 2006). The prevalence of $k a t \mathrm{G}$ and $i n h \mathrm{~A}$ mutations, as well the frequency and type of gene mutations, varies greatly among different geographic regions, with ranges of $35-91 \%$ and $20-35 \%$, respectively (Piersimoni \& Scarparo 2003, Silva et al. 2003, Costa et al. 2009). The inclusion of other genes, such as the $\operatorname{oxy} R$ - $a h p C$ intergenic region, may increase the sensitivity of the test, although the relationship between INH resistance and mutations in this region are

TABLE III

Comparison of the results obtained for the identification of GenoType MTBDRplus with the sequencing and with LINE-TB/MDR

\begin{tabular}{|c|c|c|c|c|c|c|c|c|c|c|}
\hline & \multicolumn{2}{|c|}{$\begin{array}{l}\text { Results } \\
(\mathrm{n}=65)\end{array}$} & \multicolumn{8}{|c|}{$\begin{array}{l}\text { Compared results } \\
\qquad(\mathrm{n}=65)\end{array}$} \\
\hline & $\begin{array}{l}\text { Hain } \\
\text { strip }\end{array}$ & Seq & $\begin{array}{l}\text { Hain strip } \\
\text { wt/Seq wt }\end{array}$ & $\begin{array}{l}\text { Hain strip } \\
\text { mut/Seq wt }\end{array}$ & $\begin{array}{l}\text { Hain strip } \\
\text { wt/Seq mut }\end{array}$ & $\begin{array}{l}\text { Hain strip } \\
\text { mut/Seq mut }\end{array}$ & $\begin{array}{c}\text { Kappa } \\
(95 \% \text { CI })\end{array}$ & $\mathrm{p}$ & $\begin{array}{l}\text { SE } \\
(\%)\end{array}$ & $\begin{array}{l}\text { SP } \\
(\%)\end{array}$ \\
\hline $\begin{array}{l}\text { INH wt } \\
\text { INH res }\end{array}$ & $\begin{array}{l}27 \\
38\end{array}$ & $\begin{array}{l}25 \\
40\end{array}$ & 25 & 3 & 2 & 40 & $\begin{array}{c}96.9 \\
(89.9-98.6)\end{array}$ & $<0.001$ & 87.0 & 100.0 \\
\hline $\begin{array}{l}\text { RMP wt } \\
\text { RMP res }\end{array}$ & $\begin{array}{l}28 \\
37\end{array}$ & $\begin{array}{l}25 \\
40\end{array}$ & 25 & 0 & 3 & 37 & $\begin{array}{c}90.5 \\
(84.3-86.4)\end{array}$ & $<0.001$ & 92.5 & 100.0 \\
\hline & $\begin{array}{l}\text { Hain } \\
\text { strip }\end{array}$ & $\begin{array}{l}\text { LINE-TB/ } \\
\text { MDR }\end{array}$ & $\begin{array}{c}\text { Hain strip } \\
\text { wt/LINE-TB/ } \\
\text { MDR wt }\end{array}$ & $\begin{array}{l}\text { Hain strip } \\
\text { mut/LINE-TB/ } \\
\text { MDR wt }\end{array}$ & $\begin{array}{l}\text { Hain strip } \\
\text { wt/LINE-TB/ } \\
\text { MDR mut }\end{array}$ & $\begin{array}{l}\text { Hain strip } \\
\text { mut/LINE-TB/ } \\
\text { MDR mut }\end{array}$ & $\begin{array}{c}\text { Kappa } \\
(95 \% \text { CI })\end{array}$ & $\mathrm{p}$ & & \\
\hline $\begin{array}{l}\text { INH wt } \\
\text { INH res }\end{array}$ & $\begin{array}{l}25 \\
40\end{array}$ & $\begin{array}{l}25 \\
40\end{array}$ & 25 & 0 & 2 & 38 & $\begin{array}{c}93.6 \\
(86.7-97.5)\end{array}$ & $<0.001$ & & \\
\hline $\begin{array}{l}\text { RMP wt } \\
\text { RMP res }\end{array}$ & $\begin{array}{l}28 \\
37\end{array}$ & $\begin{array}{l}25 \\
40\end{array}$ & 25 & 0 & 3 & 37 & $\begin{array}{c}87.4 \\
(84.3-96.2)\end{array}$ & $<0.001$ & & \\
\hline
\end{tabular}

CI: confidence interval; INH: isoniazid; RMP: rifampicin; SE: sensitivities; SP: specificities. 
not yet fully understood. In previous work, mutations in this gene have frequently been observed to be associated with mutations in other genes and have been found alone in very few isolates (Costa et al. 2009).

The LINE-TB/MDR method achieved satisfactory results for the identification of SNPs involved in INH resistance, with a sensitivity of $91.6 \%$ (99/108), which is similar to the performance of GenoType MTBDRplus and other commercial kits (Bonington et al. 1998, Ling et al. 2008). Our aim was to evaluate the potential contribution of a new "in-house" test for accelerating the laboratory detection of RIF and INH resistant strains, particularly when MDR-TB is suspected.

The discrepancies between the LINE-TB/MDR method and DNA sequencing might be due to (i) the specificity of the probes, (ii) the analysis of hetero-resistant strains or (iii) the lack of sensitivity of the hybridisation. It should be noted that the LINE-TB/MDR test identified three isolates as INH-resistant using $\operatorname{inh} A \mathrm{M}$ probe hybridisation, while the sequencing data identified them as WTinhA. This could be due to the higher sensitivity of the hybridisation-based assays compared to sequencing-based assays for detecting mixed bacterial populations (van Deun et al. 2009) and this issue is currently under investigation.

In summary, the LINE-TB/MDR method described in this study offers advantages over alternative techniques and provides results $6 \mathrm{~h}$ after amplification of the target, considerably decreasing the time needed for DST. We are now in a second-phase trial for the evaluation of the reproducibility of this test in different laboratories. The hope is that this test will be an additional tool for the diagnosis of MDR-TB and will be routinely applied in laboratories in regions with high TB and TB/HIV burdens and limited financial resources.

\section{ACKNOWLEDGEMENTS}

To all patients and their families.

\section{REFERENCES}

Ajbani K, Nikam C, Kazi M, Gray C, Boehme C, Balan K, Shetty A, Rodrigues C 2012. Evaluation of genotype MTBDRsl assay to detect drug resistance associated with fluoroquinolones, aminoglycosides and ethambutol on clinical sediments. PLOS ONE 7: 1-6.

Arago LM, Alcaide F, Borrell S, Carden E, Jose J, Martin-Casabona N, Moreno C, Salvado M, Coll P 2007. Multicenter laboratory evaluation of the MB/BacT Mycobacterium detection system and the BACTEC MGIT 960 system in comparison with the BACTEC 460TB system for susceptibility testing of Mycobacterium tuberculosis. J Clin Microbiol 45: 1766-1770.

Arnold C, Westland L, Mowat G, Underwood A, Magee J, Gharbia S 2005. Single-nucleotide polymorphism-based differentiation and drug resistance detection in Mycobacterium tuberculosis from isolates or directly from sputum. J Clin Microbiol Infect 11: 122-130.

Aslan G, Tezcan S, Serin MS, Emekdas G 2008. Genotypic analysis of isoniazid and rifampin resistance in drug-resistant clinical Mycobacterium tuberculosis complex isolates in southern Turkey. Jpn J Infect Dis 61: 255-260.

Bonington A, Strang JI, Klapper PE, Hood SV, Rubombora W, Penny M, Willers R, Wilkins EG 1998. Use of roche AMPLICOR Mycobacterium tuberculosis PCR in early diagnosis of tuberculous meningitis. J Clin Microbiol 36: 1251-1254.
Brosch R, Gordon SV, Marmiesse M, Brodin P, Buchrieser C, Eiglmeier K, Garnier T, Gutierrez C, Hewinson G, Kremer K, Parsons LM, Pym AS, Samper S, van Soolingen D, Cole ST 2002. A new evolutionary scenario for the Mycobacterium tuberculosis complex. Proc Natl Acad Sci USA 99: 3684-3689.

Bwanga F, Hoffner S, Haile M 2009. Direct susceptibility testing for multidrug resistant tuberculosis: a meta-analysis. BMC Infect Dis 9: 67-74.

Campbell PJ, Morlock GP, Sikes RD, Dalton TL, Metchock B, Starks AM, Hooks DP, Cowan LS, Plikaytis BB, Posey JE 2011. Molecular detection of mutations associated with first and second-line drug resistance compared with conventional drug susceptibility testing of Mycobacterium tuberculosis. Antimicrob Agents Chemother 55: 2032-2041.

Canetti G, Rist N, Grosset J 1963. Measurement of sensitivity of the tuberculous bacillus to antibacillary drugs by the method of proportions. Methodology, resistance criteria, results and interpretation. Rev Tuberc Pneumol (Paris) 27: 217-272.

Cardoso RF, Cooksey RC, Morlock GP, Barco P, Cecon L, Forestiero F, Leite CQF, Sato DN, Shikama MDL, Mamizuka EM, Hirata RDC, Hirata MH 2004. Screening and characterization of mutations in isoniazid-resistant Mycobacterium tuberculosis isolates obtained in Brazil. Antimicrob Agents Chemother 48: 3373-3381.

Costa ERD, Marta OR, Silva MSN, Arnold LS, Rostirolla DC, Cafrune PI, Espinoza RC, Palaci M, Telles MA, Ritacco V, Suffys PN, Lopes ML, Campelo CL, Miranda SS, Kremer K, da Silva PEA, Fonseca LDS, Ho JL, Kritski AL, Rossetti MLR 2009. Correlations of mutations in $k a t \mathrm{G}$, oxy $\mathrm{R}-\operatorname{ahp} \mathrm{C}$ and $\operatorname{inh} \mathrm{A}$ genes and in vitro susceptibility in Mycobacterium tuberculosis clinical strains segregated by spoligotype families from tuberculosis prevalent countries in South America. BMC Microbiol 9: 36-39.

Crudu V, Stratan E, Romancenco E, Hillemann A, Moraru N 2012. First evaluation of an improved assay for molecular genetic detection of tuberculosis as well as rifampin and isoniazid. J Clin Microbiol 50: 1264-1269.

Dorman SE, Chihota VN, Lewis JJ, Shah M, Clark D, Grant AD, Churchyard G, Fielding KL 2012. Performance characteristics of the cepheid Xpert MTB/RIF test in a tuberculosis prevalence survey. PLOS ONE 7: e43307.

Hillemann D, Weizenegger M, Kubica T, Richter E, Niemann S 2005. Use of the genotype MTBDR assay for rapid detection of rifampin and isoniazid resistance in Mycobacterium tuberculosis complex isolates. J Clin Microbiol 43: 3699-3703.

Kozhamkulov U, Akhmetova A, Rakhimova S, Belova E 2011. Molecular characterization of rifampicin and isoniazid-resistant $M y$ cobacterium tuberculosis strains isolated in Kazakhstan. Jpn J Infect Dis 64: 253-255.

Laurenzo D, Mousa SA 2011. Mechanisms of drug resistance in Mycobacterium tuberculosis and current status of rapid molecular diagnostic testing. Acta Trop 119: 5-10.

Lawn SD, Mwaba P, Bates M, Piatek A, Alexander H, Marais BJ, Cuevas LE, McHugh TD, Zijenah L, Kapata N, Abubakar I, McNerney R, Hoelscher M, Memish ZA, Migliori GB, Kim P, Maeurer M, Schito M Zumla A 2013. Advances in tuberculosis diagnostics: the Xpert MTB/RIF assay and future prospects for a point-of-care test. Lancet Infect Dis 13: 349-361.

Ling DI, Zwerling AA, Pai M 2008. GenoType MTBDR assays for the diagnosis of multidrug-resistant tuberculosis: a meta-analysis. Eur Respir J 32: 1165-1174.

Loddenkemper R, Hauer B 2010. Drug-resistant tuberculosis: a world wide epidemic poses a new challange. Medicine 107: 9-10.

Mäkinen J, Marttila HJ, Marjamäki M, Viljanen K, Soini H, Ma J, Marjama M, Viljanen MK 2006. Comparison of two commercial- 
ly available DNA line probe assays for detection of multidrugresistant Mycobacterium tuberculosis. J Clin Microbiol 44: 1-4.

Malhotra S, Cook VJ, Wolfe JN, Tang P, Elwood K, Sharma MK 2010. A mutation in Mycobacterium tuberculosis rpoB gene confers rifampin resistance in three HIV-TB cases. Tuberculosis 90: 152-157.

Maschmann RA, Spies SF, Nunes LN, Zaha A, Rossetti MLR 2013. Performance of the GenoType ${ }^{\circledR}$ MTBDRplus assay directly on sputum specimens from Brazilian patients with tuberculosis treatment failure or relapse. J Clin Microbiol 3: 67-72.

Maschmann RA, Verza M, Silva MSN, Sperhacke RD, Ribeiro MO, Suffys PN, Gomes HM, Tortoli E, Marcelli F, Zaha A, Rossetti MLR 2011. Detection of rifampin-resistant genotypes in Mycobacterium tuberculosis by reverse hybridization assay. Mem Inst Oswaldo Cruz 106: 139-145.

Michelon CT, Rosso F, Schmid KB, Sperhacke RD, Oliveira MM, Kritski AL, Rezende Jr L, Costa ERD, Ribeiro AW, Verza M, Cafrune PI, Silva MSN, Kuhleis D, Zaha A, Rossetti MLR 2011. Colorimetric microwell plate reverse-hybridization assay for Mycobacterium tuberculosis detection. Mem Inst Oswaldo Cruz 106: 194-199.

MS - Ministério da Saúde Brasil 2010. Manual de recomendações para o controle da tuberculose no Brasil, Secretaria de Vigilância em Saúde/Programa Nacional de Controle da Tuberculose, Brasília, 186 pp.

Padmapriyadarsini C, Narendran G, Swaminathan S 2011. Diagnosis e treatment of tuberculosis in HIV co-infected patients. Indian $J$ Med Res 134: 850-865.

Palomino JC 2009. Molecular detection, identification and drug resistance detection in Mycobacterium tuberculosis. FEMS Imunol Med Microbiol 56: 103-111.

Piersimoni C, Scarparo C 2003. Relevance of commercial amplification methods for direct detection of Mycobacterium tuberculosis complex in clinical samples. J Clin Microbiol 41: 5355-5365.

Ramaswamy S, Musser JM 1998. Molecular genetic basis of antimicrobial agent resistance in Mycobacterium tuberculosis: 1998 update. Tuber Lung Dis 79: 3-29.

Rouse DA, DeVito JA, Li Z, Byer H, Morris SL 1996. Site-directed mutagenesis of the kat $\mathrm{G}$ gene of Mycobacterium tuberculosis: effects on catalase-peroxidase activities and isoniazid resistance. Mol Microbiol 22: 583-592.

Rylance J, Pai M, Lienhardt C, Garner P 2010. Priorities for tuberculosis research: a systematic review. Lancet Infect Dis 10: 886-892.

Sekiguchi J, Miyoshi-akiyama T, Augustynowicz-Kopeć E, Zwolska Z, Kirikae F, Toyota E, Kobayashi I, Morita K, Kudo K, Kato S, Kuratsuji T, Mori T, Kirikae T 2007. Detection of multidrug resistance in Mycobacterium tuberculosis. J Clin Microbiol 45: 179-192.

Silva MSN, Senna SG, Ribeiro MO, Valim ARM, Telles MA, Kritski A, Morlock GP, Cooksey RC, Zaha A, Rossetti MLR, Silva SN,
Valim RM 2003. Mutations in $k a t \mathrm{G}$, inh $\mathrm{A}$ and $a h p \mathrm{C}$ genes of Brazilian isoniazid-resistant isolates of Mycobacterium tuberculosis. J Clin Microbiol 41: 1-5.

Smith NH, Dale J, Inwald J, Palmer S, Gordon SV, Hewinson RG, Smith JM 2003. The population structure of Mycobacterium bovis in Great Britain: clonal expansion. Proc Natl Acad Sci USA 100: 15271-15275.

Sreevatsan S, Pan X, Stockbauer KE, Connell ND, Kreiswirth BN, Whittam TS, Musser JM 1997. Restricted structural gene polymorphism in the Mycobacterium tuberculosis complex indicates evolutionarily recent global dissemination. Proc Natl Acad Sci USA 94: 9869-9874.

van Deun A, Barrera L, Bastian I, Fattorini L, Hoffmann H, Kam KM, Rigouts L, Ru S, Wright A 2009. Mycobacterium tuberculosis strains with highly discordant rifampin susceptibility test results. J Clin Microbiol 47: 3501-3506.

van Soolingen D, de Haas PE, Hermans PW, van Embden JD 1994. DNA fingerprinting of Mycobacterium tuberculosis. Methods Enzymol 235: 196-205.

Verza M, Maschmann RA, Silva MSN, Costa ERD, Ribeiro MO, Rosso F, Suffys PN, Tortoli E, Marcelli F, Zaha A, Rossetti MLR 2009. In house colorimetric reverse hybridisation assay for detection of the mutation most frequently associated with resistance to isoniazid in Mycobacterium tuberculosis. Mem Inst Oswaldo Cruz 104: 710-714.

Vilch C, Jacobs WR 2007. The mechanism of isoniazid killing: clarity through the scope of genetics. Annu Rev Microbiol 61: 35-50.

Watterson SA, Wilson SM, Yates MD, DrobniewskiFA 1998. Comparison of three molecular assays for rapid detection of rifampin resistance in Mycobacterium tuberculosis. J Clin Microbiol 36: 1969-1973.

WHO - World Health Organization 2010. Multidrug and extensively drug-resistant TB (M/XDR-TB): 2010 global report on surveillance and response. Available from: who.int/tb/ publications/2010/978924599191/en/.

WHO - World Health Organization 2011. Global tuberculosis control 2011. WHO report 2011. Available from: who.int/tb/publications/ global_report/2011/gtbr11_full.pdf.

WHO - World Health Organization 2012. "Totally drug-resistant" tuberculosis: a WHO consultation on the diagnostic definition and treatment options. Available from: who.int/tb/challenges/xdr/ xdrconsultation/en/.

Zaczek A, Brzostek A, Augustynowicz-kopec E, Zwolska Z, Dziadek J 2009. Genetic evaluation of relationship between mutations in rpoB and resistance of Mycobacterium tuberculosis to rifampin. BMC Microbiol 8: 1-8.

Zhang M, Yue J, Yang Y, Zhang H, Lei J, Jin R, Zhang X, Wang H 2005. Detection of mutations associated with isoniazid resistance in Mycobacterium tuberculosis isolates from China. J Clin Microbiol 43: 1-7. 
Probe set for identification of the wild type (WT) and mutant genotypes

\begin{tabular}{lcccc}
\hline Probes & $\begin{array}{c}\text { Sequence } \\
\left(5^{\prime}-3 '\right)\end{array}$ & $\begin{array}{c}\text { Length } \\
(\mathrm{bp})\end{array}$ & WT & $\begin{array}{c}\text { Probes concentration } \\
(\mathrm{pmol} / \mu \mathrm{L})\end{array}$ \\
\hline Rif1wt & CAGCCAGCTGAGCCAATTCAT & 21 & WT & 5.0 \\
Rif2wt & TTCATGGACCAGAACAACCC & 20 & WT & 10.0 \\
Rif3wt & CGCTGTCGGGGTTGACC & 17 & WT & 10.0 \\
Rif4wt & TTGACCACAAGCGCCGACT & 20 & WT & 5.0 \\
Rif5wt & CTGTCGGCGCTGGGGC & 16 & Mutant & 10.0 \\
Rif1M & CCAATTCATGGTCCAGAA & 21 & Mutant & 5.0 \\
Rif2M & GTTGACCTACAAGCGCCG & 18 & Mutant & 10.0 \\
Rif3M & GGTTGACCGACAAGCGCC & 18 & Mutant & 10.0 \\
Rif4M & CTGTTGGCGCTGGGGC & 16 & Mutant & 10.0 \\
Rif5M & CGACTGTGGGCGCTGG & 16 & WT & 10.0 \\
$k a t G w t$ & TCACCAGCGGCATCGAG & 17 & Mutant & 0.4 \\
$k a t G M$ & TCACCACCGGCATCGAG & 17 & WT & 0.4 \\
inhAwt & CGGCGAGACGATAGGTTGTC & 20 & WT & 0.6 \\
IS6110 & TGCCCGTCCCGCCGATCTC & 18 & & 1.0 \\
\hline
\end{tabular}

Primers used for amplification and standardisation of multiplex PCR for genes rpoB, $k a t \mathrm{G}$, inhA and IS6110

\begin{tabular}{|c|c|c|}
\hline Gene & Primer sequence (5'-3') & $\begin{array}{l}\text { Size } \\
\text { (bp) }\end{array}$ \\
\hline \multirow[t]{2}{*}{ IS6110 } & IS1 CGTGAGGGCATCGAGGTGGC & 245 \\
\hline & IS2 Bio-GCGTAGGCGTCGGTGACAAA & \\
\hline \multirow[t]{2}{*}{ rpoB } & Rif1 GGTCGCCGCGATCAAGGAGT & 157 \\
\hline & Rif2 Bio-TGCACGTCGCGGACCTCCA & \\
\hline \multirow[t]{2}{*}{ kat $\mathrm{G}$} & katG1 CATGAACGACGTCGAAACAG & 232 \\
\hline & katG2 Bio-CGAGGAAACTGTTGTCCCAT & \\
\hline \multirow[t]{2}{*}{$\operatorname{inh} \mathrm{A}$} & inhA1 CCTCGCTGCCCAGAAAGGGA & 248 \\
\hline & inhA2 Bio-ATCCCCCGGTTTCCTCCGGT & \\
\hline
\end{tabular}

